\title{
ENGINEERING GERMINATION FITNESS FOR SUB-PHYSIOLOGICAL TEMPERATURES IN PLANTS
}

\section{HUSSAIN JAVEED1, LIBAO CHENG², FEI SONG1, GUANGXIAO YANG1 AND GUANGYUAN HE1}

${ }^{1}$ China-UK HUST-RRes Genetic Engineering and Genomics Joint Laboratory; International Science and Technology Cooperation Base (Genetic Engineering) of Chinese Ministry of Science and Technology; HUST Base of Chinese National Center of Plant Gene Research (Wuhan), The Key Laboratory of Molecular Biophysics of Chinese Ministry of Education; College of Life Science and Technology, Huazhong University of Science and Technology (HUST), Wuhan, 430074, China

${ }^{2}$ Hubei Bioinformatics and Molecular Imaging Key Laboratory, College of Life Science and Technology, HUST, Wuhan, 430074, China

*Corresponding Author: Email- hegy@hust.edu.cn

Received: April 11, 2012; Accepted: May 10, 2012

\begin{abstract}
Germination is a key event in plant life cycle and imbibition temperature is an important factor for the major reorganization processes in the germinating seeds. Sub-physiological temperature at this stage affects virtually all aspects of cellular function including protein folding, kinetic parameters of membrane fluidity, protein assembly, and general metabolic processes. In this article we will review the research which has been carried out to decipher the basic mechanisms of low temperature (LT) stress with special emphasis on germination. With the better understanding of $L T$ tolerance in some plant species we will also discuss how these attributes can be transferred in the important food crops to attain better germination stamina at sub-physiological temperatures. At germination stage, the cellular machinery in the embryo is not at its proper place and is going through reorganisation and any environmental severity has devastating effects on the fragile plant. But LT resistant species have evolved the ability to acclimatise, with the remodelling of cell and tissue structures and the reprogramming of metabolism and gene expression. Metabolic networks are redirected towards the synthesis of cryoprotectant molecules, which in association with other proteins bring about physical and biochemical restructuring of cell membranes through changes in the lipid composition and induction of other non-enzymatic proteins that alter the freezing point of water. Genetic engineering of crops for enhanced seed germination performance will certainly help to achieve optimum agricultural yields.
\end{abstract}

Key words- Sub-physiological temperatures, Imbibition temperature, Germination physiology, Chilling injury, Energy metabolism

Citation: Hussain Javeed, et al. (2012) Engineering Germination Fitness for Sub-Physiological Temperatures in Plants. International Journal of Molecular Biology, ISSN: 0976-0482 \& E-ISSN: 0976-0490, Volume 3, Issue 2, pp.-43-48.

Copyright: Copyright@2012 Hussain Javeed, et al. This is an open-access article distributed under the terms of the Creative Commons Attribution License, which permits unrestricted use, distribution, and reproduction in any medium, provided the original author and source are credited.

\section{Germination physiology in low temperature}

All environmental stresses disrupt the normal functioning of a living system. To re-establish metabolic homeostasis, living systems require an adjustment of metabolic pathways in a process usually referred to as acclimation. For temperate plants, low temperature (LT) is a major non-living element of the environmental that affects water and nutrient uptake, membrane fluidity and protein and nucleic acid conformation, drastically influencing cellular metabolism directly by reducing the rates of biochemical reactions [1], accompanied by changes in the transcriptome, proteome and metabolome [2]. Chilling temperatures $\left(0\right.$ to $\left.15^{\circ} \mathrm{C}\right)$ frequently occur in nature and affect many species of plants, especially those of tropical origin (such as rice, corn, tomato and soybean), by causing wilting, chlorosis, or necrosis, thus restricting their growth and development. Metabolic rates are lowered which create energy imbalance.

Freezing $\left(0^{\circ} \mathrm{C}\right.$ and below) temperatures cause membrane injury [3], decrease the respiration rate and ATP content [4], resulting in poor germination, reduced seedling emergence, decreased seedling vigour, and ultimately severe loss in yield of the food crops of tropical and subtropical origins [5-9]. Embryos, excised from seed coats of soybeans, leak profusely during the first minutes of imbibition. In the embryos imbibed at $10^{\circ} \mathrm{C}$ or lower, disproportionately more solutes leak out per unit of water imbibed. Short periods of imbibition at or below $12{ }^{\circ} \mathrm{C}$ to $14^{\circ} \mathrm{C}$ reduce embryo germination and axis elongation. Injury results from imbibition at $2^{\circ} \mathrm{C}$ for as 
little as 5 minutes [10]. A significant alteration in organelle ultrastructure was observed in the soybean axes which were imbibed at $10^{\circ} \mathrm{C}$ and $4^{\circ} \mathrm{C}$, with the loss of cristae in mitochondria, an irregular cytoplasmic layer and an undeveloped endoplasmic reticulum structure [11].

Chilling injury $(\mathrm{Cl})$ is defined as the damage incurred by living cells during exposure to sub-physiological temperatures. Particularly membranes lose their selective permeability and many cellular components are released including lipids, proteins and ions. Low temperature severely affects the agricultural yields of temperate crops and limits their geographical distribution. In this article we will take an overview of the research which has been carried out to decipher the basic mechanisms of low temperature stress with special emphasis on the most important part of plant life cycle, the germination. We will also discuss how the information gathered from immense scientific efforts can be used to engineer important food crops with better germination at sub-physiological temperatures.

\section{Low temperature effects seed germination}

Traditional concept of germination is defined as the embryonic axis protrudes. Mature seed of a flowering plant contains an embryo; a non-growing plant axis, which resumes its growth when placed in physiologically favourable conditions for plant seed germination [12]. Germination incorporates those events that commence with imbibition by the quiescent dry seed and terminate with the elongation of the embryonic axis [13]. Timing of germination is determined by the temperature and water potential thresholds for radical emergence [14, 15]. Water uptake acts as a switch for setting up discrete mechanisms for seed germination. Essential metabolic activities are resumed and hydrated enzymes are activated to produce energy for the subsequent growth processes [16, 17]. After sensing a number of environmental signals, seeds tend to germinate when conditions are favourable for seedling establishment and completion of the life cycle, to ensure subsequent growth and development of the plant.

For germinating seeds, low temperature interferes with the ability of the embryo to be transformed from a quiescent body into a metabolically active organ [10], resulting in failure of germination and poor growth vigour. Chilling-resistant cultivars can stand the low temperature imbibition and germinate well, whereas the seed germination process is severely affected in chilling sensitive phenotypes [18-22]. Cheng et al. [23] observed that the soybean seeds imbibed at $22^{\circ} \mathrm{C}$ germinated within $24 \mathrm{~h}$, whereas seeds imbibed at $4^{\circ} \mathrm{C}$ did not germinate within $24 \mathrm{~h}$. When transferred to $22^{\circ} \mathrm{C}$, germination was observed in about $20 \%$ of the seeds. Even 5 min of imbibition at $2^{\circ} \mathrm{C}$ reduced both germination and subsequent elongation of axes [24]. Exploring the potentials of chilling resistant cultivars with further elaboration of imbibitional process has great prospects in plant breeding, in the future.

Imbibition is defined as the period from the beginning of water uptake by the dry seeds to the emergence of the radicle. The imbibition of water, at normal physiological temperatures, converts the seed from a quiescent body with very low respiratory rate into a dynamic organism, active in respiration, biosynthesis, and capable of growth [25]. The classical triphasic time course of seed imbibition reflects the initial rapid absorption of water by the dry seed (Phase I), followed by a period of variable length where seed wa- ter content is relatively constant (Phase II), and a resumption of water uptake associated with expansion and growth of the embryo (Phase III) [26].

The restoration of the cell membrane, and DNA and protein synthesis using existing mRNAs occurs in the phase I, while mitochondrial synthesis and protein synthesis using newly synthesized mRNAs commence in phase II [13]. Within 20 min of imbibition at $25^{\circ} \mathrm{C}$, an extensive reorganization of membrane structures occurs in the outer layers of cells in soybean seeds [10].

Cheng et al. (2010) studied the changes in water absorption by changes in soybean seed weight during imbibition at $4^{\circ} \mathrm{C}$ and $22^{\circ}$ $\mathrm{C}$ for $24 \mathrm{~h}$. It was observed that the seeds imbibed at $22^{\circ} \mathrm{C}$ could absorb more water than those at $4^{\circ} \mathrm{C}$ during the same period. During phase I, seeds absorbed water rapidly, which slowed down in phase II, but it increased again in phase III. However, for the seeds imbibed at $4^{\circ} \mathrm{C}$, the time would be delayed because of the temperature influence. Interestingly, the transcriptional level of four up-regulated genes was lower at $6 \mathrm{~h}$ and $12 \mathrm{~h}$ than that at $1 \mathrm{~h}$ and $24 \mathrm{~h} \mathrm{[23].}$

\section{Membrane damage at chilling temperatures}

Imbibition temperature is a key factor for the membrane reorganization processes; when normal lamellar phospholipid structure of plasma membrane is being restored, the ER is reforming, and mitochondria are returning to a hydrated configuration [27-30]. Leakage of solutes at this stage is in fact a manifestation of membrane reorganization in the outer layers of cells, and temperatures below $20^{\circ} \mathrm{C}$ cause increasing damage to the reorganizing membranes, which approach the degree of solute leakiness of the dead tissues at $1^{\circ} \mathrm{C}$, which is 10 -fold higher than the living tissues [ 10 , 17, 29, 31-33]. Extensive internal disruption may occur, if membrane restoration is impaired [10].

A greater leakage of solutes during imbibition may both deplete the tissues of soluble food reserves, and stimulate growth of pathogenic microorganisms [34]. Altered leakage patterns were observed in soybean embryos with $30 \%$ moisture content, imbibed at temperatures from 6 to $25^{\circ} \mathrm{C}$ and then germinated on moist filter paper at $28^{\circ} \mathrm{C}$ for 3 days. Germination was reduced by imbibition at $12^{\circ} \mathrm{C}$ or less, with the greatest reduction at $6^{\circ} \mathrm{C}$. It was ascertained that leakage was correlated with the chilling injury and ratios of leakage to water uptake show that at lower temperatures, disproportionately greater amounts of solutes were lost per unit of water uptake [24].

Chilling resistant species have higher proportion of unsaturated fatty acids and correspondingly a lower transition temperature [35]; a temperature at which a phase change occurs, altering the functions of both the membranes and their associated enzyme systems [28, 36]. It has been observed that emergence of cotton seeds from a cold soil was positively correlated with the unsaturated/saturated fatty acid ratio of total and membrane lipids [37, 38]. Changes in lipid metabolism, such as induction of desaturases enhance the stability of cell membranes by increasing the desaturation of fatty acids in membrane lipids [39-42]. It has been observed that mitochondrial ROS accumulation during chilling imbibition was increased, which may also contribute to plasma membrane damage [11]. GST24 was up-regulated in soybean seeds imbibed at $4^{\circ} \mathrm{C}$ [23], which helps to protect plasma membranes from chilling damage by detoxification of xenobiotics and toxic 
endogenous products [43]. MDH was also up-regulated, which is one of the more active enzymes in peroxisomes, mitochondria, chloroplast, glyoxysomes, and cytoplasm [23].

\section{Stress omics}

Recent advances in genomics, transcriptomics, metabolomics, bioinformatics, and user friendly analytical tools have been fundamental in the current understanding of regulatory networks that control abiotic stress responses. Genomic approaches have contributed in identifying whole pathways involved in abiotic stress response and their relationships to the whole metabolic network [44]. Gene expression profiling has allowed the identification of hundreds of genes induced when plants are exposed to stress, giving a more comprehensive picture of changes occurring in the transcriptome across different conditions [45-48].

Some of the transcript profiling technologies such as CDNA-AFLP, SAGE, MPSS, and quantitative real time PCR (qRT-PCR) allow us to perform an assessment of high-throughput expression of thousands of genes in control and stress-treated tissues at various developmental stages [44, 46, 49-52]. Functional genomics helps to identify gene, gene function, and to understand the relationship between phenotype and genotype via integrated functional genomic approach [53, 54]. Organ specific and stress-responsive expression of the introduced genes is not possible without tissue specific promoters. In this regard, genomic tools identified a set of stress-inducible genes, and their cis-acting elements in the promoters can now be isolated and thoroughly tested for specificity $[44,55]$.

Comparative genomics helps to transfer knowledge obtained from model species to applications in agriculture [56, 57]. Generation of expressed sequence tags (ESTs) from cDNA libraries prepared from abiotic stress-treated seedlings of various crops, provide a valuable resource to discover stress related genes [44, 46, 58, 59]. Changes in plant proteome brought about by the stress are manifested as the up- or down-regulation of proteins, or in their post-translational modification [60,61]. High throughput proteomic techniques help to capture the various states of dynamic proteome in a cell comprehensively, and make it possible to sample and analyse the proteome in different conditions and at several time points following perturbation to provide new insights into the chilling stress responses.

Metabolomics is the analysis of the complete pool of small metabolites in a cell at any given time $[62,63]$. In germinating seeds, low temperature dramatically affects essential metabolic activities and activation of hydrated enzymes to produce energy for the subsequent growth processes [16, 17]. Plants need to modulate and establish a new homeostasis of all primary metabolisms, such as metabolisms of carbon, nitrogen, sulphur and all other metabolic fluxes particularly those connected with the generation and consumption of reducing equivalents and ATP $[64,65]$. Comprehensive profiling of stress-associated metabolites and metabolic engineering is an effective strategy for enhancing low temperature tolerance $[66,67]$.

Although the molecular mechanism for germinating seeds to adapt to hostile conditions is unclear, plants respond to environmental stresses through physiological and biochemical processes, alteration of ultrastructure, and molecular and cellular signal transduction processes [68-70]. The first step in plant responses to the modification of their environment depends on their ability to detect the stimulus, leading to the transduction of a signal in the plant cell that ultimately leads to the activation of the appropriate genetic programs [71]. Signalling pathways constitute networks that are interconnected at many levels [71]. Along with other potential sensors, plasma membrane has been considered as a site for the perception of temperature change [72-75] and cells can sense cold stress through low temperature-induced changes in membrane fluidity, and activate signal transduction pathways, leading to changes in expression of many gene networks. This signalling may induce the secretion of hormones which amplify the initial signal and initiate a second round of signalling. In this way, plant responds to stresses as individual cells and synergistically as a whole organism [35].

According to the functions of their products, genes induced by stress could be categorized into two groups. Genes in the first group have rapid and transient expression and encode functional proteins such as membrane proteins; key enzymes for osmolyte biosynthesis; the detoxification enzymes; and other proteins for the protection of macromolecules. The second group comprises regulatory proteins, i.e. transcription factors (bZIP, MYC, MYB and DREB, etc.), protein kinases and proteinases, involved in the regulation of signal transduction and gene expression $[35,46,50,76-$ 83]. Some of the important transcription regulons control the expression of tens of genes in response to low temperature stress. Thomashow's group identified 514 CBF2 target cold-responsive genes [51]. Maruyama et al. [49] performed transcriptome analysis in transgenic plants overexpressing DREB1a/CBF3 conferring strong tolerance to freezing stress and identified 38 up-regulated genes, known to participate in freezing tolerance.

\section{Energy metabolism in germinating seeds}

Respiratory activity in seeds becomes apparent after about 10 minutes of imbibition [17] and mitochondrial oxidative phosphorylation is the main pathway, which provides energy to the seed axis during imbibition [11]. Understanding working of mitochondria at low temperatures can certainly help to engineer crops with better power houses - mitochondria - to cope with sub-physiological temperatures. Mitochondria are functionally "immature" in the seeds before germination and develop to fully functional organs during imbibition [84-89]. Yin et al. [11] found that after imbibition at $22^{\circ} \mathrm{C}$ for $24 \mathrm{~h}$ soybean axes' cells have all the cell organelles in fully functional form, whereas in the axes imbibed at 10 and $4^{\circ} \mathrm{C}$ it was difficult to find endoplasmic reticulum, the intercellular space was looser and the cytoplasmic layer was irregular (also see Fig. 1)

Kinetics of most metabolic reactions are highly temperature dependent [90]. The seeds imbibed at $22^{\circ} \mathrm{C}$ well establish an intact electron transport chain and respiration as compared with the seeds imbibed at 10 and $4^{\circ} \mathrm{C}$ [11]. Chilling stress could change the oxygen consumption in mitochondria, produce reactive oxygen species (ROS), and disturb the efficiency and the pathways of electron transport chains and decrease the production of ATP. Additionally, mitochondrial biogenesis is also inhibited during chilling treatment [11]. In proteomic analysis of germinating soybean seeds under chilling temperatures of $4^{\circ} \mathrm{C}$ Cheng et al. found that the level of transcript encoding alpha-subunit of ATP synthase 
was up-regulated. It catalyses the terminal step in oxidative respiration, generating ATP from the electrochemical gradient for cellular biosynthesis. To fulfil the energy requirements, two essential enzymes of glycolysis and TCA cycle, triose phosphate isomerase (TPI) and phosphoenolpyruvate carboxylase (PEPC), were also up-regulated in soybean germinating seeds, when exposed to low temperatures of $4^{\circ} \mathrm{C}[23]$.

Cold stress affects virtually all aspects of cellular function and it is therefore perhaps not surprising that plant cold acclimation responses are highly integrated into cellular function at all levels [1]. Here we will have an overview of some the important genes which are induced in plants, specifically to cope with the low temperature stress. Genetic modulation of these genes in agricultural crop species in germination stage, can give them better fitness in low temperature conditions.

Some HSPs increase in abundance following exposure to low temperature, and have a strong cryoprotective effect, participating in membrane protection [91, 92]. PR proteins $\beta$-1,3-glucanases, chitinases and thaumatin-like proteins have antifreeze activity in the apoplastic space, which inhibit the recrystallization of intercellular ice, and prevent the formation of intracellular ice [91, 93, 94]. It has been observed that several dehydrin proteins accumulate in response to LT stress [23, 91, 95-97], which protect the proteins from denaturation when the cytoplasm becomes dehydrated.

Increased late embriogenesis abundant (LEA) protein level in soybean early germinating seedlings, reduce the electrolyte leakage after desiccation and subsequent rehydration (in case of imbibition) [21]. LEA protein was up-regulated in germinating soybean seeds under low temperature conditions [23]. Level of expression of two water stress related proteins, ADH and RAB21 was also up -regulated. $\mathrm{ADH} 1$ plays an important role in low-oxygen tolerance $[98,99]$. So it can be said that the seeds imbibed at low temperature, not only suffer from low temperature injury but also low oxygen stress.

\section{Engineering germination fitness for suboptimal temperature}

Where the severity of the stress is more progressive, tolerant plants have evolved the ability to acclimatise, with the remodelling of cell and tissue structures and the reprogramming of metabolism and gene expression [100-102]. Metabolism is redirected towards synthesis of cryoprotectant molecules such as soluble sugars, sugar alcohols and low-molecular weight nitrogenous compounds [74, 103-107], which in conjunction with other proteins bring about physical and biochemical restructuring of cell membranes through changes in the lipid composition and induction of other nonenzymatic proteins that alter the freezing point of water.

Being soluble in water and non-toxic at high concentrations, sucrose and other simple carbohydrates contribute in cold acclimation by stabilizing the membrane and protecting it against freezedamage, by decreasing the freezing point of water to a more negative value $[35,105,108,109]$. Sucrose and other oligosaccharides have been shown to be effective cryoprotectants [108, 110, 111]. Some plants respond to cold stress by the synthesis of antifreeze proteins that inhibit the activity of ice nucleators [112, 113]. De novo protein synthesis is necessary for cold response and the integrity of the translation machinery is an important factor of cold acclimation [1]. Chilling injury can also be greatly reduced if seeds have high moisture content before imbibition at low temperature
[10].

Understanding gene expression associated with germination will provide avenues for genetic engineering of crop plants for enhanced seed germination performance. Regulons at the transcription level and transcription factors represent some of the best targets for engineering plants to achieve enhanced cold tolerance [114]. DRE/DREB regulon can be used to improve the tolerance of various kinds of agriculturally important crop plants to low temperature as well as other stresses by gene transfer [82].

Constitutive overexpression of the Arabidopsis CBF genes in canola results in increased freezing tolerance [64]. Induction of the COR genes was accomplished by over-expression of CBF, which resulted in increased freezing as well as drought tolerance $[115,116]$. Ectopic expression of CBF proteins in plants enhances freezing tolerance and leads to constitutive expression of COR genes in non-acclimated, transgenic Arabidopsis plants [40, 117] Overexpression of the CBF3 also increased the tolerance to drought, high-salinity, and freezing stresses [40, 115, 118]. Overexpression of $\mathrm{CBF} 3$ conferred strong tolerance to freezing stress [49], and 38 genes known to enhance low temperature tolerance were up-regulated [119].

Metabolic engineering is also an effective strategy for enhancing chilling tolerance $[66,69]$. Some of the stress-inducible genes that encode proteins, such as key enzymes for osmolyte biosynthesis, LEA proteins, and detoxification enzymes have been overexpressed in transgenic plants and produce stress-tolerant phenotypes in the transgenic plants [120].

\section{Outlook}

Germination is a key event, where the plant in the form of a delicate embryo leaves all of its protective coverings and steps in to a new world to go for another plant life cycle. Engineering embryo to stand against all the environmental odds, especially low soil temperatures can make a real difference in agricultural yields. Low temperature resistance is multi-genic and plant breeders face a daunting task in trying to transfer low temperature resistance to low temperature-sensitive plants. Understanding of the key mechanisms controlling germination, by using comprehensive quantitative and qualitative approaches, analyses of gene expression products at the transcriptome, proteome and metabolome levels, are likely to pave the way for studies of regulatory networks underlying the functioning of germinating seeds in given physiological situations.

Genetically engineered low temperature stress adaptations would certainly help to achieve optimum yields and development of sustainable agriculture. Genes involved in signalling and regulatory pathways should be given top priority in plant engineering strategies for low temperature stress. Transcription regulons are one of the best targets to achieve enhanced low temperature tolerance. For minimum disturbance in the natural machinery, more research needs to be focused on appropriate low temperature stress inducible tissue specific promoters and transcription factors to control the timing as well as intensity of expression of low temperature stress genes in the desired tissue as well as cellular location.

\section{References}

[1] Achard P., Gong F., Cheminant S., Alioua M., Hedden P. and Genschik P. (2008) The Plant Cell Online 20, 2117. 
[2] Agarwal P., Agarwal P., Reddy M. and Sopory S. (2006) Plant Cell Reports, 25, 1263-1274.

[3] Allagulova C., Gimalov F., Shakirova F. and Vakhitov V. (2003) Biochemistry (Moscow) 68, 945-951.

[4] Angus J., Cunningham R., Moncur M. and Mackenzie D. (1981) Field Crops Research (Netherlands).

[5] Attucci S., Carde J., Raymond P., Saint-Ges V., Spiteri A. and Pradet A. (1991) Plant Physiology 95, 390.

[6] Bartkowski E., Buxton D., Katterman R. and Kircher H. (1977) Agronomy Journal, 69, 37.

[7] Bedi S. and Basra A. (2008) Seed Science Research 3, 219229.

[8] Bewley J. (1997) Plant Cell 9, 1055-1066.

[9] Bewley J. and Black M. (1994) Seeds: physiology of development and germination.

[10]Bramlage W., Leopold A. and Parrish D. (1978) Plant Physiology 61,525 .

[11]Buchanan C., Lim S., Salzman R., Kagiampakis I., Morishige D., Weers B., Klein R., Pratt L., Cordonnier-Pratt M. and Klein P. (2005) Plant molecular biology 58, 699-720.

[12]Carpenter J. and Crowe J. (1988) Cryobiology 25, 244.

[13]Chang M., Chien W., Chao C. and Lu M. (2009) Carbohydrate Polymers.

[14]Chen T. and Murata N. (2008) Trends in Plant Science 13, 499 -505 .

[15]Chen W., Provart N., Glazebrook J., Katagiri F., Chang H., Eulgem T., Mauch F., Luan S., Zou G. and Whitham S. (2002) The Plant Cell Online 14, 559 .

[16]Chinnusamy V., Zhu J. and Zhu J. (2007) Trends in Plant Science 12, 444-451.

[17]Cigan A., Unger E., Xu R., Kendall T. and Fox T. (2001) Sexual Plant Reproduction 14, 135-142.

[18]Clay W., Bartkowski E. and Katterman F. (1976) Physiologia Plantarum 38, 171-175.

[19]Covell S., Ellis R., Roberts E. and Summerfield R. (1986) Journal of Experimental Botany 37, 705.

[20]Cushman J. and Bohnert H. (2000) Current Opinion in Plant Biology 3, 117-124.

[21]Dahal P. and Bradford K. (2008) Seed Science Research 4, 71-80.

[22]Deltour R. (1985) Journal of Cell Science 75, 43.

[23]Ehrenshaft M. and Brambl R. (1990) Plant Physiology 93, 295.

[24]Fowler S. and Thomashow M. (2002) The Plant Cell Online 14, 1675-1690.

[25]Gallois J., Achard P., Green G. and Mache R. (2001) Gene 274, 179-186.

[26]Garcia-Huidobro J., Monteith J. and Squire G. (1982) Journal of Experimental Botany 33, 288.

[27] Gilmour S., Sebolt A., Salazar M., Everard J. and Thomashow M. (2000) Plant Physiology 124, 1854-1865.

[28]Griffith M. and Yaish M. (2004) Trends in Plant Science 9, 399 $-405$.

[29] Gusta L., Wisniewski M., Nesbitt N. and Gusta M. (2004) Plant Physiology 135, 1642-1653.

[30]Guy C. (1990) Annual Review of Plant Biology 41, 187-223.

[31]Guy C., Haskell D. and Li Q. (1998) Cryobiology 36, 301-314.

[32] Guy C., Kaplan F., Kopka J., Selbig J. and Hincha D. (2008) Physiologia Plantarum 132, 220-235.
[33]Hallam N., Roberts B. and Osborne D. (1972) Planta 105, 293 $-309$.

[34] Hare P., Cress W. and Van Staden J. (1998) Plant Cell and Environment 21, 535-553.

[35]Harrigan G. and Goodacre R. (2003) Metabolic profiling: its role in biomarker discovery and gene function analysis.

[36]lba K. (2002) Annual Review of Plant Biology 53, 225-245.

[37]Ismail A., Hall A. and Close T. (1999) National Academy of Sciences 96, 13566.

[38]Jaglo-Ottosen K., Gilmour S., Zarka D., Schabenberger 0. and Thomashow M. (1998) Science 280, 104-106.

[39]Jaglo K., Kleff S., Amundsen K., Zhang X., Haake V., Zhang J., Deits T. and Thomashow M. (2001) Plant Physiology 127, 910-917.

[40]Jung S., Lee J. and Lee D. (2003) Plant molecular biology 52, 553-567.

[41]Kacperska A. (1999) Cold-adapted organisms: ecology, physiology, enzymology, and molecular biology, 79.

[42]Kasuga M., Liu Q., Miura S., Yamaguchi-Shinozaki K. and Shinozaki K. (1999) Nature biotechnology 17, 287-291.

[43]Kawamura Y. and Uemura M. (2003) The Plant Journal 36, 141-154.

[44]Kidd F. and West C. (1919) New Phytologist, 35-39.

[45]Knight H. and Knight M. (2001) Trends in Plant Science 6, 262 $-267$.

[46]Kovacs D., Kalmar E., Torok Z. and Tompa P. (2008) Plant Physiology 147, 381.

[47]Kratsch H. and Wise R. (2000) Plant Cell and Environment 23, 337-350.

[48]Kreps J., Wu Y., Chang H., Zhu T., Wang X. and Harper J. (2002) Plant Physiology 130, 2129.

[49]Kyauk, H., Hopper, N. and Brigham, R. (1995) Environmental and Experimental Botany 35, 345-351.

[50]Lee B., Henderson D. and Zhu J. (2005) The Plant Cell Online 17,3155 .

[51]Leopold A. (1980) Plant Physiology 65, 1096.

[52]Libao Cheng, X. G., Shuyan Li, Mengjun Shi, Hussain Javeed, Xinming Jing, Guangxiao Yang, Guangyuan He (2010) Molecular Breeding 26, 1-17.

[53]Liu Q., Kasuga M., Sakuma Y., Abe H., Miura S., YamaguchiShinozaki K. and Shinozaki K. (1998) The Plant Cell Online 10, 1391-1406.

[54]Logan D., Millar A., Sweetlove L., Hill S. and Leaver C. (2001) Plant Physiology 125, 662.

[55]Lyons J. (1973) Annual Review of Plant Physiology 24, 445466.

[56]Mahajan S. and Tuteja N. (2005) Archives of biochemistry and biophysics 444, 139-158.

[57]Mantri N., Ford R., Coram T. and Pang E. (2007) BMC genomics $8,303$.

[58]Mark T. and Antony B. (2005) Plant Physiol 137, 791?793.

[59]Maruyama K., Sakuma Y., Kasuga M., Ito Y., Seki M., Goda H., Shimada Y., Yoshida S., Shinozaki K. and YamaguchiShinozaki K. (2004) The Plant Journal 38, 982-993.

[60]Mayer A. and Poljakoff-Mayber A. (1963) The germination of seeds. 236.

[61]McDonald Jr M., Vertucci C. and Roos E. (1988) Crop Science $28,993$. 
[62]Moffatt B., Ewart V. and Eastman A. (2006) Physiologia Plantarum 126, 5-16.

[63]Moons A. (2005) Vitamins and hormones 72, 155.

[64]Morohashi Y. and Bewley J. (1980) Plant Physiology 66, 70.

[65]Murata N., Ishizaki-Nishizawa O., Higashi S., Hayashi $\mathrm{H}$., Tasaka Y. and Nishida I. (1992) Nature 356, 710-713.

[66]Nawa Y. and Asahi T. (1971) Plant Physiology 48, 671.

[67]Nawa Y. and Asahi T. (1973) Plant Physiology 51, 833.

[68]Nijsse J., Walther P. and Hoekstra F. (2007) Seed Science Research 14, 117-126.

[69]Obendorf R. and Hobbs P. (1970) Crop Science 10, 563.

[70]Oono Y., Seki M., Satou M., lida K., Akiyama K., Sakurai T., Fujita M., Yamaguchi-Shinozaki K. and Shinozaki K. (2006) Functional and Integrative Genomics 6, 212-234.

[71]Park E., Jeknic Z., Sakamoto A., DeNoma J., Yuwansiri R., Murata N. and Chen T. (2004) Plant Journal 40, 474-487.

[72]Parrish D. and Leopold A. (1977) Plant Physiology 59, 1111.

[73]Paterson A., Freeling M. and Sasaki T. (2005) Genome research 15, 1643

[74]Pearce R. (1999) Plant Growth Regulation 29, 47-76.

[75]Pollock B. (1969) Plant Physiology 44, 907.

[76]Posmyk M., Corbineau F., Vinel D., Bailly C. and C鬽e D. (2001) Physiologia Plantarum 111, 473-482.

[77]Qureshi M., Qadir S. and Zolla L. (2007) Journal of plant physiology 164, 1239-1260.

[78]Raison J. (1973) 485.

[79]Raison J. (1980) The Biochemistry of plants: a comprehensive treatise (USA)

[80]Renaut J., Hausman J. and Wisniewski M. (2006) Physiologia Plantarum 126, 97-109.

[81]Romeis T. (2001) Current Opinion in Plant Biology 4, 407-414.

[82]Satoh R., Nakashima K., Seki M., Shinozaki K. and Yamaguchi-Shinozaki K. (2002) Plant Physiology 130, 709.

[83]Scheibe R. (2004) Physiologia Plantarum 120, 21-26.

[84]Schulz F. and Bateman D. (1969) Phytopathology 59, 352355.

[85]Seki M., Kamei A., Yamaguchi-Shinozaki K. and Shinozaki K. (2003) Current Opinion in Biotechnology 14, 194-199.

[86]Seki M., Narusaka M., Ishida J., Nanjo T., Fujita M., Oono Y., Kamiya A., Nakajima M., Enju A. and Sakurai T. (2002) The Plant Journal 31, 279-292.

[87]Seki M., Okamoto M., Matsui A., Kim J., Kurihara Y., Ishida J., Morosawa T., Kawashima M., To T. and Shinozaki K. (2009) Molecular Techniques in Crop Improvement, 333-355.

[88]Shanks J. (2005) AIChE journal 51, 2-7.

[89]Shiao T., Ellis M., Dolferus R., Dennis E. and Doran P. (2002) Biotechnology and bioengineering 77, 455-461.

[90]Shinozaki K. and Yamaguchi-Shinozaki K. (2000) Current Opinion in Plant Biology 3, 217-223.

[91]Simon E. (1974) New Phytologist 73, 377-420.

[92]Simon E. and Wiebe H. (1975) New Phytologist, 407-411.

[93]Sreenivasulu N., Sopory S. and Kavi Kishor P. (2007) Gene 388, 1-13.

[94]Steponkus P., Uemura M., Joseph R., Gilmour S. and Thomashow M. (1998) Proceedings of the National Academy of Sciences of the United States of America 95, 14570.

[95]Stewart J. and Guinn G. (1969) Plant Physiology 44, 605.
[96]Stockinger E., Gilmour S. and Thomashow M. (1997) Proceedings of the National Academy of Sciences 94, 1035.

[97]Strauss G. and Hauser H. (1986) Proceedings of the National Academy of Sciences 83, 2422.

[98]Tena G., Asai T., Chiu W. and Sheen J. (2001) Current Opinion in Plant Biology 4, 392-400.

[99]Thomashow M. (1999) Annual Review of Plant Biology 50, 571-599.

[100]Thomashow M. (2001) Plant Physiology 125, 89-93.

[101]Timperio A., Egidi M. and Zolla L. (2008) Journal of Proteomics 71, 391-411.

[102]Uemura M., Tominaga Y., Nakagawara C., Shigematsu S., Minami A. and Kawamura Y. (2006) Physiologia Plantarum 126, 81-89.

[103]Valluru R., Lammens W., Claupein W. and Van den Ende W. (2008) Trends in Plant Science 13, 409-414.

[104]van de Mortel J. and Aarts M. (2006) New Phytol 170, 199201.

[105]Vaultier M., Cantrel C., Vergnolle C., Justin A., Demandre C., Benhassaine-Kesri G., 水鏴k D., Zachowski A. and Ruelland E. (2006) FEBS letters 580, 4218-4223.

[106]Vergnolle C., Vaultier M., Taconnat L., Renou J., Kader J., Zachowski A. and Ruelland E. (2005) Plant Physiology 139, 1217.

[107]Vinocur B. and Altman A. (2005) Current Opinion in Biotechnology 16, 123-132.

[108]Viswanathan C. and Zhu J. (2002) Philosophical Transactions of the Royal Society B: Biological Sciences 357, 877.

[109]Vogel J., Zarka D., Van Buskirk H., Fowler S. and Thomashow M. (2005) The Plant Journal 41, 195-211.

[110]Vuong T., Wu X., Pathan M., Valliyodan B. And Nguyen H. (2008) Genomics-assisted Crop Improvement: Genomics applications in crops, 243.

[111]Vuylsteke M., Daele H., Vercauteren A., Zabeau M. and Kuiper M. (2006) Plant Journal 45, 439-446.

[112]Wang W., Vinocur B. and Altman A. (2003) Planta 218, 1-14.

[113]Wanner L. and Junttila O. (1999) Plant Physiology 120, 391.

[114]Webster B. and Leopold A. (1977) American Journal of Botany 64, 1286-1293.

[115]Welbaum G., Bradford K., Yim K., Booth D. and Oluoch M. (2008) Seed Science Research 8, 161-172.

[116]Wisniewski M. and Fuller M. (1999) Cold-Adapted Organisms Ecology, Physiology, Enzymology and Molecular Biology, 105118.

[117]Xiong L., Schumaker K. and Zhu J. (2002) The Plant Cell Online 14, 165

[118]Yamaguchi-Shinozaki K. and Shinozaki K. (2006) Annu. Rev. Plant Biol. 57, 781-803.

[119]Yin G., Sun H., Xin X., Qin G., Liang Z. and Jing X. (2009) Plant and Cell Physiology 50, 1305.

[120]Zhang X., Fowler S., Cheng H., Lou Y., Rhee S., Stockinger E. and Thomashow M. (2004) The Plant Journal 39, 905-919. 